\title{
RESPONSE
}

\section{After the Prison Closes: Seeking Healing, Memory and Awareness at P4W Linda Mussell}

There are many paths leading to the mountaintop, and so when a person is confronted with an insurmountable obstacle blocking their way, it might be necessary to take a different path, or sometimes a person must stop and rest before they can go on. But as long as they never lose sight of the mountaintop, it will remain their guiding beacon no matter what kind of adverse conditions or detours they may face along the way.

- Ann Hansen (2018, p. 197).

$\mathrm{W}$ hat does it mean to create a memorial on the grounds of a prison that has already shut down? The Prison for Women (P4W) in Kingston, Ontario, Canada closed its doors in 2000 (CSC, 2000), but the prison building and surrounding grounds have not shed their meaning for many. It is a site with social history and memory, which institutional closure does not erase, especially for those who have direct experiences in $\mathrm{P} 4 \mathrm{~W}$ as prisoners. As a woman at P4W described, "You may think that everything is alright now that $\mathrm{P} 4 \mathrm{~W}$ is being shut down, but what did it take to do that?" (Horii, 1994, p. 12). Creating a memorial on the grounds of a prison that has closed means seeking to build healing, awareness, and memory regarding the effects of the prison which once was, and the ongoing effects of prisons still open.

P4W served as the sole prison for federally sentenced women in Canada from 1934 to 2000 (CSC, 2000). Over that time, thousands of women were imprisoned there, in conditions described as "disgraceful" in 1938 (Archambault, 1938, p. 314), "unfit for bears, much less women" in 1977 (MacGuigan, 1977, p. 135), and "cruel, inhumane, and degrading" in 1996 (Arbour, 1996, p. 51). Women from P4W described the "archaic conditions, arbitrary mass punishment, sexism, and racial barriers" (Sugar and Fox, 1989, p. 468) of the prison. Prisoners were experimented on in unethical scientific studies in the 1960s (Gilmore and Somerville, 1998). ${ }^{1}$ Many women also died at P4W. As one woman at P4W expressed, "Grief is too present in my life” (Mayhew, 1997, p. 75). ${ }^{2}$ The prison was slated for closure 
in 1999 by the Solicitor General and decommissioned in 2000 (CSC, 2000). Since then the prison building and grounds sat empty, and has recently been purchased for commercial development (Nease, 2018). ${ }^{3}$ When creating a memorial on the grounds of a prison that has closed, it is important to ensure that the history of the prison is not lost in this development.

Women with direct experiences at $\mathrm{P} 4 \mathrm{~W}$ have created a group to advocate accounting for this history. The P4W Memorial Collective seeks to create a memorial garden on the grounds for $\mathrm{P} 4 \mathrm{~W}$, a mission members have been pursuing for several years. ${ }^{4}$ The Collective is made up of women who were formerly imprisoned at $\mathrm{P} 4 \mathrm{~W}$, as well as local advocates in the community who wish to support them (e.g. Guenther, 2018). In this work, the importance of voice and guiding direction from the women who were imprisoned in $\mathrm{P} 4 \mathrm{~W}$ is paramount. As women from $\mathrm{P} 4 \mathrm{~W}$ have stated, "The starting point for action lies not in abstract discussion, but in the experiences of the women themselves" (Sugar and Fox, 1989, p. 469). Maintaining the primacy of former prisoner perspectives in this work is a subject of on-going discussion within the Collective. For example, the Collective has created a council of women formerly incarcerated at P4W who no longer live in Kingston, to help ensure their voices are better reflected. In this context, it is especially important to acknowledge that I am an advocate member of the group and not a former prisoner. While my perspectives are informed by our discussions, I lack the material experiences and insights that former prisoners in the Collective have.

The closure of P4W in Kingston falls under broader national and global patterns of prison closure and redevelopment or repurposing(Wilson et al., 2017). Sites developed for penal tourism such as museums, tours, and hotels are often the outcomes, as opposed to projects that better represent the experiences and perspectives of prisoners. ${ }^{5}$ This is important, as prison sites advance narratives, and these narratives influence meaning-making, namely what Canadians come to understand incarceration and punishment to be (Walby and Piché, 2015). The efforts and work of advocacy groups to influence the narrative in situations of prison redevelopment are not always highly visible. That said, there are examples of advocates successfully developing memorials in the memory of prisoners. These range from former prisoners successfully advocating for a memorial in the early 1990s at the former Berlin-Hohenschönhausen prison in Berlin, Germany (Byrnes, 2017), to an on-going memorial project led by 
prisoners' relatives and allies at the former Women's Prison of Les Corts in Barcelona, Spain (EUROM, 2018). Our group seeks to bring greater visibility to the memorial work being done at $\mathrm{P} 4 \mathrm{~W}$ in Kingston - work that requires community awareness and support to sustain it.

Remembering and acknowledging the history of a prison also means drawing attention to on-going experiences of imprisonment in Canada. When P4W closed, six more institutions opened in its place (CSC, 2013a). Even when new prisons are opened with promises of reforms, prisoners report that changes can be dubious (Glaremin, 2011), and may disappear "like bunnies in the magicians hat - an illusion" (Hansen, 2018, p. 340). ${ }^{6}$ In these new prisons, women in Canada are being incarcerated at an increasing rate, and Indigenous women in particular are overrepresented (Reitano, 2017; Malakieh, 2018). ${ }^{7}$ The reasons for imprisonment are complex, and as women from $\mathrm{P} 4 \mathrm{~W}$ explained, often predicated by conditions of violence. In fact, "Our stories show that we have all been the victims of violence" (Sugar and Fox, 1989, p. 470). Women from P4W further expressed that this violence increases behind bars, because "When we come to prison, we need to adjust to greater and greater violence in our lives" (Cree, 1994, p. 46). Memorializing a prison which has closed means acknowledging institutional histories, as well as the on-going imprisonment of people and associated harms. This includes documenting the experiences of prisoners currently incarcerated, people who are in the process of transitioning back to the community, and people whose life conditions mean that they may become incarcerated for the first time or multiple times over their lives. As articulated by a former prisoner, "I pretty much did not have a chance right from the womb, and it's no one's fault" (Acoose, 2011, p. 47).

When memorializing a prison that has closed, areas of intervention will be different in each case. With P4W, the sale and future development of the prison presents the need to advocate for an acknowledgement of the prison's social histories in the new development. For example, maintaining the historical features of the building, such as locks and windows, can eclipse the view suggesting someone was once imprisoned behind them. ${ }^{8}$ In the sale of prison property, acknowledgement that the land and building is not simply a commodity, but was a place of imprisonment, can be lost. A focus on developing the building and land for future profit can overshadow understanding that many women lost their futures there. It is essential to help people remember what the prison is - it can never just be a commodity. 
There are numerous ways of helping the community and country remember the history of a prison that has closed and the on-going processes of imprisonment. These vary widely, including film screenings, education campaigns, community partnerships, art installations, vigils and more. In this project, the Collective is driven by the vision of the former women who were incarcerated at P4W and what they identify as important. Objectives of healing, memorialisation and community awareness have emerged as significant in discussions of the closed prison. While the Collective engages in more than one form of memorialisation, for example holding an annual Prisoner's Justice Day vigil, its overarching goal is to develop a memorial garden. The former prisoners in the group express that a living, physical place carved-out from the grounds of the prison to remember the women they knew personally is important to achieving our objectives.

Acknowledging and centring the experiences of Indigenous prisoners in memorializing a prison that has closed is integral, and it is one reason why we advocate for a living memorial on the land of the original custodians. There are other groups following the same vision across Canada. For example, local groups are creating healing forests in honour of residential school survivors in Winnipeg, Manitoba, Edmonton, Alberta, and Perth, Ontario (Dacey, 2018; Tree Canada, 2018). Further, a reconciliation grove prototype was developed by Métis Cree student, James Bird, at the University of Toronto (U of T, 2017). As Bird states, "The idea is that we can gauge the health of reconciliation by how this tree grows... reconciliation is a live, growing process" (U of T, 2017). Importantly, a living memorial garden has been expressed by Indigenous women involved in the work of the Collective as essential for healing. Trees and plants which grow and change, just as the women who were imprisoned grow and change, are held as key features. Although the design of the P4W memorial garden will transform as the development project progresses, the idea of a living memorial is an essential piece in this project.

Memorializing a prison that has closed means amplifying the experiences of people who were incarcerated there - not only within the Collective, but in the community and beyond. It is important to seek space for public awareness of social impacts of the former prison, a history which is not greatly acknowledged in Kingston despite serving as the location of several prisons, open and closed. ${ }^{9}$ Prisons are landmarks of interest on trolley tours, there are guided tours at KP (St. Lawrence Parks Commission, 2018; also 
see Piché et al., 2019), and the Correctional Service of Canada operates a museum within the former KP Warden residence (CSC, 2017; also see Walby and Piché, 2011). However, there are no spaces in Kingston dedicated to remembering and reflecting on those who are among the most marginalized and silenced in society. As conveyed by a woman from P4W, "Prisons represent that end of the system where we put the most readily detected, the most readily prosecuted, and the most readily forgotten about" (Stewart, 1997, p. 103).

P4W was the sole federal women's prison in Canada for several decades, closed in part due to unacceptable conditions and treatment of prisoners. Women from that prison have created the Collective at the grassroots level to help the community and country remember. What does it mean to memorialize a prison which has closed? It means centring the voices of former prisoners from the institution, accounting for the history of the site and on-going processes of incarceration in other sites, and seeking opportunities for action which open when the prison doors close.

\section{ENDNOTES}

1 Experiments included sensory deprivation, behavioural modification, electro-shock therapy and experimental pharmacology (e.g., LSD). Prisoners across Canada have come forward with their experiences, including a former prisoner at P4W, Dorothy Proctor, in 1995 (Osborne, 2006). Proctor later brought a lawsuit against CSC in 1998 (CBC News, 1998).

2 It is unknown how many women in total died at P4W. Some members of the Collective personally remember the seven women who died by suicide in P4W between 1988 and 1991, including six who were Indigenous (Hansen, 2018).

3 P4W was purchased by Queen's University in 2007 and initial plans included housing university archives in the building (Girard, 2007). The interior of the building was awarded heritage designation shortly following this purchase (City of Kingston, 2007), which may have rendered prospective renovations prohibitively difficult. Queen's sold the prison to ABNA Investments Inc. in 2018 (Nease, 2018).

4 Members began this work several years before the official creation of the Collective.

5 Within Kingston, for example, KP has been transformed into a prison tour destination (Ferguson et al., 2014; Piché et al., 2019), and the former KP Warden's house across the street is now used as a CSC museum. There has been discussion of removing internal features of $\mathrm{P} 4 \mathrm{~W}$ to be incorporated into the KP tours or the CSC museum (City of Kingston, 2018).

6 The regional institutions are not the great improvement from P4W promised (see CSC, 2013b). For example, the institutions fall short on meaningful employment, appropriate infrastructure, educational resources, and mental health support (Office of the Correctional Investigator, 2017). 
7 In the ten-year period between 2007/08 and 2016/17, the number of federally sentenced women increased by $29.7 \%$. The number of federally sentenced Indigenous women increased by $60 \%$ over the same period (Office of the Correctional Investigator, 2017).

8 The heritage designation of P4W has figured heavily in City Council and developer discussions regarding its redevelopment (City of Kingston, 2018).

9 There are nine federal prisons in the Kingston region including seven within the city's municipal borders. Three are now closed (KP, the Regional Treatment Centre, and P4W).

\section{REFERENCES}

Arbour, Louise (1996) Commission of Inquiry into Certain Events at the Prison for Women in Kingston, Ottawa: Public Works and Government Services Canada.

Archambault, Joseph (1938) Report to the Royal Commission to Investigate the Penal System of Canada, Ottawa: J. O. Patenaude, I.S.O.

Acoose, Sharon (2011) "My Healing Journey", Journal of Prisoners on Prisons, 20(1): 47-56.

Byrnes, Deidre (2017) "Remembering at the Margins: Trauma, Memory Practices and the Recovery of Marginalised Voices at the Berlin-Hohenschönhausen Memorial", Journal of Contemporary European Studies, 25(4): 455-469.

CBC News (1998) "Former inmate sues over LSD experiments", CBC News - October 7. Retrieved from $<$ https://www.cbc.ca/news/canada/former-inmate-sues-over-lsdexperiments-1.166674>.

City of Kingston (2018) "Report to Council. Former Prison for Women - Potential Re-development Considerations", City of Kingston. Retrieved from $<$ https://www. cityofkingston.ca/documents/10180/27117742/City-Council_Meeting-16-2018_ Report-18-191_Former-Prison-For-Women-Potential-Re-developmentConsiderations.pdf/a885bb97-6132-4fbe-8746-75c2956c3ccd>.

City of Kingston (2007) "2007-167 A By-Law To Designate 40 Sir John A. Macdonald Boulevard, Also Known As 'The Prison For Women (P4W)' To Be Of Cultural Heritage Value Pursuant To The Provisions Of The Ontario Heritage Act (R.S.O. 1990, Chapter 0.18)", City of Kingston. Retrieved from $<$ https://www.cityofkingston. ca/cok/bylaws/2007/doc/doc926614.PDF>.

Cree, Ms. (1994) "Entrenched Social Catastrophe", Journal of Prisoners on Prison, 5(2): 45-47.

Correctional Service of Canada [CSC] (2000) The Closing of the Prison for Women in Kingston in Kingston July 6, 2000, Ottawa. Retrieved from <http://www.csc-scc. gc.ca/text/pblct/brochurep4w/index-eng.shtml>.

CSC (2017) "Correctional Service of Canada Museum”, Ottawa. Retrieved from $<\mathrm{http} / /$ www.csc-scc.gc.ca/about-us/006-1002-eng.shtml>.

CSC (2013a) "Regional Facilities for Women Offenders 1995 [Archived]", Ottawa. Retrieved from $<$ http://www.csc-scc.gc.ca/text/pblct/rht-drt/14-eng.shtml $>$.

CSC (2013b) "Women's Facilities", Ottawa. Retrieved from $<$ http://www.csc-scc.gc.ca/ women/002002-0002-eng.shtml>.

Dacey, Elisha (2018) "Healing Forest to be Grown in Winnipeg Park", CBC News February 11. Retrieved from $<$ https://www.cbc.ca/news/canada/manitoba/healingforest-grown-winnipeg-park-1.4530753>. 
EUROM - European Observatory on Memories (2018) "Future Memorial of the Women's Prison of Les Courts", EUROM. Retrieved from <http://europeanmemories.net/ projects/womens-prison-of-les-corts-future-memorial/>.

Ferguson, Matthew, Elizabeth Lay, Justin Piché and Kevin Walby (2014) "The Cultural Work of Decommissioned Carceral Sites: Representations of Confinement and Punishment at Kingston Penitentiary", Scapegoat: Landscape, Architecture, Political Economy, 7: 83-98.

Gilmore, Norbert and Margaret Somerville (1998) A Review of The Use of LSD and ECT at the Prison for Women in the Early 1960s, Ottawa: Correctional Service of Canada.

Girard, Daniel (2007) "Former prison for women now part of Queen's", The Star September 14. Retrieved from <https://www.thestar.com/news/2007/09/14/former_ prison_for_women_now_part_of_queens.html $>$.

Glaremin, T.A. (2011) "A New Direction for Federally Sentenced Women, Foiled Once Again", Journal of Prisoners on Prisons, 20(1): 84-88.

Guenther, Lisa (2018) "What is Lost When We Pave Over a Prison", The Globe and Mail - July 6. Retrieved from https://www.theglobeandmail.com/opinion/articlewhat-is-lost-when-we-pave-over-a-prison/.

Hansen, Ann (2018) Taking the Rap: Doing Time for Society's Crime, Toronto: Between the Lines.

Horii, Gayle K. (1994) “Disarm the Infamous Thing”, Journal of Prisoners on Prisons, 5(2): 10-22.

MacGuigan, Mark (1977) Report to Parliament. The Sub-Committee on the Penitentiary System in Canada, Standing Committee on Justice and Legal Affairs, Ottawa: Ministry of Supply and Services Canada.

Malakieh, Jamil (2018) "Adult and Youth Correctional Statistics in Canada, 2016/2017", Juristat - June 19. Retrieved from <https://www150.statcan.gc.ca/n1/pub/85002-x/2018001/article/54972-eng.htm>.

Mayhew, Jo-Ann (1997) “The Bear and Me”, Journal of Prisoners on Prisons, 8(1\&2): 75-78.

Nease, Kristy (2018) "Developer eyes Kingston's shuttered women's prison", $C B C$ News - June 26. Retrieved from $<$ https://www.cbc.ca/news/canada/ottawa/kingstonwomen-prison-future-plan-1.4720690>.

Office of the Correctional Investigator [OCI] (2017) Annual Report 2016-2017, Ottawa. Retrieved from <http://www.oci-bec.gc.ca/cnt/rpt/annrpt/annrpt20162017-eng. $\operatorname{aspx}>$.

Osborne, Geraint B. (2006) "Scientific Experiments on Canadian Inmates, 1955 to 1975", The Howard Journal of Criminal Justice, 45(3): 284-306,

Piché, Justin, Matthew Ferguson and Kevin Walby (2019) "A 'win-win for everyone involved' Except Prisoners: Kingston Penitentiary Tours as an Exercise in Staff, Media and Public Relations", Annual Review of Interdisciplinary Justice Research, 8: 91-119.

Reitano, Julie (2017) "Adult correctional statistics in Canada, 2015/2016", Juristat. Retrieved from <https://www150.statcan.gc.ca/n1/pub/85-002-x/2017001/ article/14700-eng.htm>.

St. Lawrence Parks Commission (2018) "Kingston Pen Tours", Kingston. Retrieved from $<$ https://www.kingstonpentour.com/ $>$. 
Stewart, Melissa (1997) "Prison for Women's Invisible Minority”, Journal of Prisoners on Prisons, 8(1\&2): 91-104.

Sugar, Fran and Lana Fox (1989) "Nistum Peyako Seht'wawin Iskwewak: Breaking Chains", Canadian Journal of Women \& Law, 3: 465-482.

Tree Canada (2018) "National Healing Forests Project Launched Across Canada" - June 19. Retrieved from <https://treecanada.ca/blog/national-healing-forests-projectlaunched-across-canada/ $>$.

University of Toronto [U of T] (2017) "Reconciliation Grove: $U$ of T student James Bird designed Words to Form - an Architectural Model for a Potential Memorial" - May 17. Retrieved from $<$ https://www.utoronto.ca/news/reconciliation-grove-u-tstudent-designs-memorial-facilitate-conversation-canada-s-relationship $>$.

Walby, Kevin and Justin Piché (2015) "Making Meaning out of Punishment: Penitentiary, Prison, Jail, and Lock-up Museums in Canada", Canadian Journal of Criminology and Criminal Justice, 57(4): 475-502.

Walby, Kevin and Justin Piché (2011) "The Polsemy of Punishment and Memorialization: Dark Tourism and Ontario's Penal History Museums", Punishment \& Society, 13(4): 451-472.

Wilson, Jacqueline Z., Sarah Hodgkinson, Justin Piché and Kevin Walby (eds.) (2017) The Handbook of Prison Tourism, London: Palgrave-Macmillan.

\section{ABOUT THE AUTHOR}

Linda Mussell is a PhD Candidate in the Department of Political Studies at Queen's University in Kingston, Ontario, Canada. She is a member of the P4W Memorial Collective which seeks to create a memorial garden on the grounds of the former Prison for Women in Kingston. Her doctoral work builds on experiences volunteering in the justice-involved community, prior research on the justice system, and work with the Institute for Intersectionality Research and Policy at Simon Fraser University. Her dissertation features intersectionality-based policy analysis (IBPA) of intergenerational incarceration and Indigeneity in Canada, Australia, New Zealand, and the United States. She can be contacted at linda.mussell@, queensu.ca. 